\title{
14
}

\section{THE CHALLENGES OF AIR SUPPORT}

\author{
Jim Campbell, Bob Supple, Bob Askew, \\ Robert O’Neill and Bill Davies
}

\section{Editors' introduction}

Air support played an important part in most operations that 5th Battalion, the Royal Australian Regiment (5 RAR), undertook during the Vietnam War. Helicopters were ideally suited to the type of warfare and difficult terrain of Vietnam and they provided a level of air mobility, close fire support, air resupply, air reconnaissance and casualty evacuation that had not been seen in earlier conflicts. Army pilots, who were allocated in direct support of infantry battalions during operations from the beginning of 1 ATF's (1st Australian Task Force) deployment into Phuoc Tuy Province, provide this chapter's narratives. They show the robust mutual regard which rapidly developed and long endured between them and those they supported.

\section{Jim Campbell}

No aircraft other than the helicopter could have provided ground forces with the various types of intimate air support which were essential to the nature of operations undertaken in Vietnam. The Bell UH-1 models, officially named 'Iroquois' but commonly referred to as the 'Huey', were particularly important. Troop and cargo-carrying versions, with two M60 
machine guns operated by side-door gunners, were known as 'slicks'. Heavily armed ground support versions with rapid-fire, multi-barrelled machine guns and high explosive (HE) rockets, were known as 'gunships'. In operations, slicks inserted and extracted small patrols or entire infantry units like 5 RAR, using clear areas called landing zones (LZ). They then kept them resupplied. The casualty evacuation version of the Huey was code-named Dustoff. Larger helicopters such as the Boeing $\mathrm{CH}-47$ Chinook were able to lift artillery units into and out of remote jungle and hilltop fire base locations in support of the battalion.

Slicks could provide close fire support from their side-mounted M60 machine guns. This could prove vital in infantry insertions into, and extractions from, unsecured LZs. In jungle or high rugged areas like the mountainous areas of Phuoc Tuy Province, suitable LZs were few and far between. Any suspected of being under Viet Cong surveillance could either be secured by ground forces or be 'prepared' by artillery or gunships immediately before the landing of troop-carrying slicks.

In its Dustoff role, the Iroquois could extract wounded soldiers from even the most inaccessible LZs. In thick primary jungle, casualties could be extracted by lowering, by winch cable, a vertical stretcher called a 'jungle penetrator'. With the casualty secured he could then be winched, upright, out of the jungle into the Dustoff helicopter. Casualties could be transported, in less than 30 minutes, to either the Australian Army's 1 Field Hospital or the US Army's 36 Evacuation Hospital at Vung Tau; or, if necessary, to specialist US medical facilities in Saigon within an hour. Dustoff support added greatly to the confidence and morale of our soldiers during operations.

Iroquois from both American and Australian units supported 1 ATF. 9 Squadron Royal Australian Air Force (RAAF) provided the Australian Iroquois and their aircraft used the radio call sign Albatross. US Army Aviation units provided the US Iroquois gunships and usually used lurid and macho call signs. Later in the war RAAF gunships became available and used the call sign Bushranger. So successful was the Iroquois in the Vietnam War that it endures as an iconic symbol for veterans of the air-mobile operations in which it was so extensively used.

In addition to the Iroquois, the battalion was supported by the smaller three-seat Bell Sioux 47G 3B1 helicopters. Australian Army pilots of 161 (Independent) Reconnaissance Flight (161 (Indep) Recce Flight) flew 
this type, forever associated with the Korean War. They used the radio call sign Possum and their primary roles were to provide air reconnaissance, forward air control of close air support and artillery fire and casualty evacuation using two exterior mounted stretchers. The latter capability was very important in cases where the combination of a tight extraction $\mathrm{LZ}$ and limited time precluded the use of the larger Iroquois Dustoff.

The battalion could task air-delivered fire; this was called close air support. The US Air Force provided close air support with its fixed-wing propellerdriven aircraft or jet fighter ground attack aircraft. The US Army's ground attack helicopters could also be used. The aircraft could deliver a range of ordnance including HE bombs, cluster bombs and napalm to surface targets. The US Army's gunships had very high rates of fire from both machine guns and automatic $40 \mathrm{~mm}$ grenade launchers, as well as volleyfired rockets. Close air support was invaluable against hardened installations and enemy targets outside the range of artillery. Also available for tasking was the destructive power of US Air Force B-52 strategic bombers and the high potency fire from the many rapid-fire, multi-barrelled machine guns mounted on converted C-47 transport aircraft (the Second World War military version of the venerable 1930s civilian DC3). These were then redesignated AC-47; the added 'A' to indicate their attack role. The radio call sign used by these aircraft was Spooky. Their popular nickname was 'Puff the Magic Dragon' because the 'red rain' of their voluminous tracer fire, particularly at night, suggested a fire-breathing, flying beast.

5 RAR made greater use of the different types of air support available to it during the period of Operations Canberra, Robin and Queanbeyan than at any other time during the battalion's tour of duty in Vietnam. These operations commenced with the battalion making its initial movement into the Nui Thi Vai and the Nui Toc Tien Hills areas on foot. Insertion by foot rather than helicopter was necessary to conceal the deployment of 5 RAR rifle companies from the Viet Cong. After the Viet Cong became aware of the presence of the battalion in the area, close air support was called in by the battalion as described in Chapters 6 and 14 .

The Sioux from 161 (Indep) Recce Flight provided continuous daily air support for the battalion during these operations. The helicopter section of the flight had been operating with 6 RAR on the eastern and northeastern side of the Nui Dinh hills in September 1966 so the pilots were reasonably familiar with the area. Each day a pilot was assigned to 5 RAR for the whole day to fly whatever tasks the battalion required. The pilot 
would be briefed the evening before, by the previous day's pilot, on the location of Battalion Headquarters (BHQ) and the fire support base (FSB) and where they could land. The new pilot would also be advised of all current company locations and any other relevant information for the following day.

\section{Bob Supple}

Prior to their experiences in Vietnam, all army pilots had worked or served with infantry battalions on exercises in Australia. Captain Jim Campbell DFC, who commanded the 161 (Indep) Recce Flight's helicopters, had been posted to 1 RAR for three years in Australia and Malaysia before becoming a pilot. Jim Campbell was awarded the Distinguished Flying Cross due largely to his actions during 5 RAR Operation Renmark when, on 21 February 1967, he flew Captain Tony White, the 5 RAR medical officer, into a minefield to assist our wounded personnel. Jim landed time after time in the minefield until all the wounded were evacuated to where the larger Dustoff aircraft could safely collect them. This was necessary because the stronger rotor downwash of the larger aircraft was likely to activate the sensitive anti-personnel mines.

161 (Indep) Recce Flight had operated out of Vung Tau until the end of February 1967. Then after their workshops and aircraft parking areas in the 1 ATF base were completed, they relocated alongside 5 RAR at Nui Dat. Sioux helicopters did not spend the night in the field with battalions during operations because the helicopters did not have any protection from enemy mortar attack or other action. Also, because they were difficult to conceal, their presence could give away the location of the unit they were supporting to the enemy.

Operation Canberra from 6 to 10 October 1966 involved 5 RAR's preliminary clearance of the Nui Thi Vai hills prior to Operation Robin where the battalion was tasked to secure a section of Route 15 directly overlooked by the Nui Thi Vai hills. Operation Robin was mounted to ensure the safe passage by road of 3 Brigade of the US 4 Infantry Division from Vung Tau to Bien Hoa. Sioux helicopters completed discreet aerial reconnaissance of the Nui Thi Vai area for Operation Canberra by 5 October 1966. On the following day the rifle companies and BHQ of 5 RAR commenced an approach on foot through the jungle towards the 
foothills of Nui Thi Vai. Late in the morning of 8 October, C Company suffered casualties from booby traps. The casualties were evacuated by a Dustoff Iroquois from an LZ hand-cut into the jungle by their mates.

In the early afternoon, B Company sighted a group of about 30 Viet Cong and a fire plan employing mortars, artillery and air support was prepared. $\mathrm{B}$ and C Companies were pulled back a safe distance from the Viet Cong location and artillery and mortar fire was directed onto the Viet Cong position. Then Iroquois gunships were called in and fired rockets and machine guns directly onto the Viet Cong position.

Following the gunship attack an airstrike was used to destroy any Viet Cong still occupying hardened bunkers. This airstrike was coordinated by BHQ and commenced with the arrival overhead of the US forward air controller in a light aircraft. I briefed the US forward air controller, nicknamed Birddog, on the target details and the locations of all friendly forces. When the F-100 Super Sabre ground attack aircraft arrived and started circling overhead, the forward air controller identified both enemy and friendly locations to the ground attack aircraft by means of coloured smoke grenades, which they used to help him identify their locations in the jungle. This involved somewhat lengthy radio communications between the rifle companies, BHQ and Birddog, followed by further radio communications between Birddog and the strike aircraft.

The air strike entailed an attack by two waves of F-100 jet aircraft using 500-pound bombs, napalm and cluster bomb units (CBUs). CBUs were large containers which exploded above the ground, scattering many smaller bomblets through the surrounding jungle to detonate on impact. Once the intricacies of identifying the enemy and friendly locations to the F-100s were successfully completed, the attack began. The airstrike produced thunderous engine roars, deafening explosions and clouds of dust and smoke, concluding not long before daylight ended; with a ground force follow-up then impossible before the following morning. During the afternoon of the airstrike, 1,000 rounds of mortar ammunition had been flown in by Iroquois to the mortar base plate position close to BHQ and, that night, the two Mortar Platoon sections (four $81 \mathrm{~mm}$ mortars) fired 960 rounds as a follow-up to the air strike. The ground follow-up of the air strike which took place next morning is described in Chapter 6. 
On the afternoon of 10 October, Iroquois airlifted the battalion to positions along Route 15 to commence Operation Robin which was conducted from 11 to 16 October. It involved searching for mines and booby traps and intensive patrolling along Route 15 and its conduct is described in Chapter 6. A near-tragic event during this operation was the crash of the Sioux helicopter then supporting the battalion. The pilot, Second Lieutenant Bill Davies, was flying at low level beside Route 15 when his main rotor blades appeared to strike a power pole; his aircraft crashed and was destroyed. Bill relates this incident and its aftermath later in this chapter.

The US 4 Infantry Division convoy with its own armoured vehicle and helicopter gunship support completed its passage along Route 15 by 16 October. Australian Iroquois and Sioux helicopters had once again provided command and control, reconnaissance, resupply and casualty evacuation missions for 5 RAR throughout Operation Robin. The battalion immediately readied itself for Operation Queanbeyan - the much-anticipated return to the Nui Thi Vai hills. This commenced on 17 October 1966 and was designed to destroy any Viet Cong remaining in or returning to their sanctuary. Intelligence reports had indicated that the Viet Cong were still active on Nui Thi Vai and the battalion knew that there were more installations to be dealt with.

After the deception measures described in Chapter 7, the rifle companies of the battalion moved on foot into their assigned areas around Nui Thi Vai and BHQ commenced its move to occupy the area surrounding a pagoda near the top of Nui Thi Vai. On that same afternoon BHQ with its protection elements, the Anti-Tank Platoon and the Assault Pioneer Platoon, came into heavy contact with the Viet Cong while ascending a spur of Nui Thi Vai. The contact lasted for several hours and helicopter gunships were called on to play an important role in assisting the heavily engaged Anti-Tank Platoon.

During this engagement, Second Lieutenant Bob Askew piloted a Sioux helicopter to evacuate casualties on two separate occasions, each under very difficult circumstances. Bob had to land his small helicopter on a rocky projection on the side of the steep hillside slope, in a position where the surrounding trees allowed little scope for any error in judgement. The Sioux was also at a very real risk of being shot down by enemy ground fire during its approach and departure. Despite these risks, Bob completed 
both casevac (casualty evacuation) missions. This feat of exceptional flying is covered both in Chapter 7 and in the following paragraphs, which include Bob's own description of his difficulties.

\section{Robert O’Neill}

On the first day of the operation, in the very difficult terrain of the Nui Thi Vai hills, Captain Brian Le Dan and Corporal Norm Womal were wounded, with Norm dying of his wounds before he could be evacuated to hospital. Trees and bushes were cleared around a fairly flat rock ledge to form an LZ barely large enough for a Sioux helicopter to complete the extraction of the casualties. Second Lieutenant Bob Askew performed this very difficult flying feat twice. He first picked up the wounded Brian Le Dan and flew him to where a larger Dustoff Iroquois could land. He returned later that day to retrieve Norm Womal's body. Bob's amazing skills and committed flying achieved these casevacs on this day. The challenges he faced are described below by Bob and Jim Campbell who both operated in and out of this rudimentary LZ.

As soon as Brian Le Dan was wounded, Possum 5 (Bob's call sign) was alerted. He had been repositioned from Nui Dat to an FSB alongside Route 15 where he waited until the area was made sufficiently secure for him to attempt to find an LZ. When the only available option was improved and secured, he was called forward. Captain Bob Supple, 5 RAR's assistant operations officer, guided Possum 5 onto the tiny LZ, while crouching low to avoid decapitation by its whirling rotor blades.

\section{Bob Askew}

I recall being on standby at an FSB beside Route 15 when the request came through for the first casevac. After the second one I returned to the FSB on standby for the rest of the day. With both missions the difficulties of the LZ were only part of the deal; the possibility of being exposed to Viet Cong fire by having to make my lengthy approach over steeply sloping ground, all of which could not be secured by the troops below, was the biggest concern for me. As I approached, the sounds of the fighting were plainly audible. Even while wearing a flying helmet and despite the chopper's noise, the distinctive 'whap' sound of a close one lent 
clarity to the term 'aimed ground fire'. Hearing gunfire close at hand was considered normal; being under fire wasn't - not by me! At the end of the day, sitting quietly somewhere and thinking over what I had learned, it was satisfying to know that when I was hard pushed, I was up to the job - something most of us have wondered about.

On landing to collect the first casualty I exited 'the plastic helicopter' (as it was sometimes affectionately described) for a couple of reasons. One, to check the main rotor blades as I had cut my way through some small vegetation on the approach. Two, I was sure my green pants might have turned brown during the approach. They hadn't, but I did have an urgent call in the other department. I can remember thinking at the time, while standing urinating against the rock, under the now green-tipped rotor blades, a thousand feet up on the edge of a mountain, with a rather large and noisy firefight happening close by, that this was rather a different setting for having a pee! The third and most compelling reason for stepping out of 'the office' was that I felt somewhat exposed waiting in a prominent plexiglass bubble when a nice secure rock face was close at hand.

After lifting out Brian Le Dan I delivered him to the Dustoff helicopter which was waiting in a clear area beside Route 15 . As there was no direct security there, the pilot had chosen the largest cleared area he could find with the nearest treeline about 300 metres away. I landed in front of him, not beside him, in case his side-door gunners needed to defend our exposed situation. I also asked if he would delay his departure until I had shut down and inspected my aircraft for damage. I didn't want to be left stranded on the ground with an unserviceable aircraft. To my surprise no damage was readily visible. After a second approach and departure to pick up Norm Womal's body, I returned to my standby location where our engineers thoroughly inspected the chopper and found no damage apart from about 120 centimetres of green foliage stains along the outer leading edges of both blades. I was amazed, and thankful, that the pilot had acquired no additional apertures.

Fifty years later I'm pleased to repeat my congratulations to the 5 RAR men who were involved that day. The organisation and execution needed in preparing the $\mathrm{LZ}$, the coordination required to get the right people into the right place at the right time, while fighting was ongoing, was superb; as was Bob Supple's tricky and dangerous task of guiding me in. Their efforts made the very difficult landing and departure of my aircraft achievable and contributed greatly to the success of my tasks. 


\section{Bob Supple}

The Anti-Tank Platoon remained pinned down under the weight of Viet Cong fire coming from caves and rocks further up the slope of Nui Thi Vai. The Viet Cong were too close for mortar or artillery fire to be used and supporting machine gun fire from a distant rifle company had proved ineffective and dangerous in trying to dislodge the enemy from their positions. Our commanding officer $(\mathrm{CO})$ then decided to employ two US Army Iroquois gunships who were in support of the battalion to help clear the enemy from their rocky positions.

Once all elements had marked their position with coloured smoke, the gunships commenced their attack. The direct rocket and machine gun fire of the gunships was able to penetrate the caves and rock positions from which the Viet Cong were firing their weapons, and this finally caused them to withdraw. BHQ was then able to resume its move up the Nui Thi Vai slopes to reach its objective near a hilltop pagoda. The full story of the Anti-Tank Platoon's engagement is described in Chapter 7.

Air support in the form of airborne command and control facilities, reconnaissance, resupply and casualty evacuation missions continued to be flown for the battalion throughout Operation Queanbeyan. LZs in the Nui Thi Vai area were mainly too small and hazardous for Iroquois, but they could fly water, rations and ammunition for the rifle companies to a larger LZ at battalion HQ or to the artillery FSB beside Route 15, for on-ferrying to the rifle companies by Sioux.

\section{Jim Campbell}

When I was about to take off in my Sioux from the BHQ pad at the pagoda with a load of supplies for one of the companies, the warrant officer directing my take-off gave the thumbs down signal and pointed to the side of the helicopter opposite the pilot's seat. When I got out of the aircraft to investigate, I found the exhaust pipe had cracked and broken off at the supercharger and hot exhaust discharge was going straight onto the oil lines of the Sioux. An engine failure could have occurred if I had continued with the flight, so I aborted the take-off. A mechanic was immediately flown in from Vung Tau, a replacement part was fitted, and I was back flying within an hour. 
During the clearance and search of caves encountered on the Nui Thi Vai slopes, I flew into the same difficult landing spot Bob Askew had twice used to evacuate casualties on 17 October. Bob had briefed me on the landing site, saying:

It requires a curved approach and you are committed to a landing. The rock surface is very uneven, and the rotor blades just miss the tree branches. To take off, you need to hover backwards about 30 metres and then rotate through 180 degrees and follow the same curved path out of the LZ.

I had to use this landing site over several days, to deliver bags of tear gas crystals to be used by the battalion to make the caves on Nui Thi Vai hills uninhabitable. I had already felt the effect of a slight leakage from the bags in flight on a previous day. On what I think was the last day of this mission, I made an approach to a pad near the top of the mountains on the north-west side. During the approach, I heard a dull bang and noticed a cloud of dust come out of the entrance to a cave not far from the LZ. The cloud came across the chopper as I came to a hover and my eyes became very irritated and breathing became difficult. I abandoned the approach and with laboured breathing and blurred vision, swaying through the sky for some time until the company on the ground advised that everything was back under control at the landing area. When my senses started to return to normal, I was able to return and land to complete the mission.

\section{Ron Boxall}

On 10 October 1966 Second Lieutenant Bill Davies was flying a Sioux helicopter in support of 5 RAR. He was involved in a serious crash which destroyed the helicopter and he and his passenger were injured, Bill very seriously. Since that time the incident has been the subject of speculation, with two conflicting versions of the cause. Was it 'pilot error', as some eyewitnesses inexpertly claimed, or was he shot down? After 50 years of frustration, Bill now has an opportunity to bring idle conjecture to a close. In doing so, he provides another insight into the mettle of our Possum brothers. 


\section{Bill Davies}

My first association with 5 RAR was in October 1965 during a training exercise in the Colo-Putty Training Area north-west of Sydney. The exercise in early 1966 was one of the battalion's final tests before it embarked for Vietnam in April. This was my very first job as an operational army pilot after receiving my 'wings'. In May 1966 I was posted to Vietnam as a replacement for Captain Bev Smith who, while flying a Sioux in Bien Hoa Province, had been shot in the left hand. The left hand normally operates the controls for climbing or descending and for varying engine power to suit either manoeuvre. Without the use of his left hand he made a remarkably skilful landing without further damage to the aircraft or its occupants. I visited him in the Military Hospital at Yeronga in Brisbane before I embarked for Vietnam where I found him negotiating with doctors to have his shattered left hand formed into a 'grip', so he could operate the twist-grip throttle on the collective lever of a Sioux. Subsequently, he rejoined the ranks of the army's operational helicopter pilots.

On arrival in Phuoc Tuy Province I soon encountered the familiar faces of my 5 RAR acquaintances, remembered from when I had flown in support of their exercise earlier that year. I immediately felt at home. Soon I was in the thick of incessant demands for support by the humble Sioux, officially designated a light observation helicopter. While that was the primary role of the aircraft, the versatility and reliability which made it a legend in the Korean War was reinforced by the many diverse tasks we were called upon to perform. On one occasion I was tasked with the evacuation of a Vietnamese woman from the Binh Ba rubber plantation. She had been haemorrhaging for some days after childbirth. Captain Tony White, the regimental medical officer of $5 \mathrm{RAR}$, decided that she should be evacuated to the Vietnamese hospital in Ba Ria. We secured her in the external litter on my side of the aircraft where I could keep an eye on her as we flew to $\mathrm{Ba} \mathrm{Ria}$, the province capital. I fitted her with headphones with voice connection to the flight deck. This would slightly muffle the engine noise. In the passenger seat I carried an interpreter, so the patient could be kept informed to reduce her anxiety as much as possible. A bonus was that the interpreter would help to balance the helicopter laterally. I don't recall this precaution being covered on our unit's standard operating procedures (SOPs). I delivered her to Ba Ria airstrip where a Vietnamese ambulance was to meet us. None arrived and alternative transport had to be arranged hastily. I never heard whether the woman or her child survived. 
Another evacuation, carried out about 10 kilometres north-east of Nui Dat, involved the recovery of an injured 5 RAR soldier. I made an initial attempt to fit the helicopter into a very tight landing site, but the rotor blade tips began striking tree leaves and twigs and there was no way I could safely persist with the approach. I radioed to 5 RAR personnel on the ground about cutting down a large, centrally placed tree. Its removal would give me a better chance of landing. I stayed nearby while this was undertaken but ran low on fuel before it could be accomplished. When I returned after refuelling the tree had been felled with a waist-high stump remaining. The approach was still a Rubik's Cube juggling job to get the Sioux onto the ground. With the casualty on one of the outside litters, the helicopter's reaction to the extra weight made the trees on our exit path look impossibly tall and their proximity masked any possibility of using any headwind for additional lift; all of which heightened my attention to the task. We scraped out of that one and it has been the stuff of nightmares since. The CO of 5 RAR, Lieutenant Colonel John Warr, was kind enough to commend my efforts by radio to my boss, Major Laurie Doyle, whom I omitted to tell about the hairiness of the extraction in case it was considered in breach of SOPs. However, when there was an urgent request to free heavily laden infantry from having to carrying a casualty and his equipment, a balanced, on-the-spot decision by the tasked pilot was clearly required. There was also the need to show the infantry, who constantly bore the brunt, that we were always there for them and that we were prepared to take any calculated risk to support them.

On 10 October I was flying in support of 5 RAR's part in Operation Robin. I was tasked to carry captured enemy materiel and the company quartermaster sergeant of B Company, Staff Sergeant 'Sailor' Mealing, to a designated site beside Route 15 . I remember flying very low along the road but nothing more of what followed. When I awoke in a US military hospital I was being visited by my unit commander, Laurie Doyle, and my section commander, Jim Campbell. They commiserated with me and asked me a few questions which I tried to answer, unaware that the conversation was part of an investigation being conducted into the crash.

Although I had no idea what had happened to place me in hospital, I wasn't particularly curious. There was a war on and I knew I'd find out soon enough. As far as I was concerned, I would be back piloting choppers in a few days - a week at the most! I felt quite guilty about not being back at 161 (Indep) Recce Flight pulling my weight in flying duties with my fellow pilots. My optimism and guilt both proved to be wide of 
the mark. The bones of my face and around my eyes had been broken in many places. Significant nerve damage caused sensory and muscle anomalies and I suffered severe double vision, among other problems. I vaguely understood that all this might mean the end of my flying career, only a couple of days after my 21 st birthday.

As I lay in bed my tongue felt a strand of 'spaghetti' in my mouth between my upper gums and my top lip. I tentatively began pulling at this strand with my fingers but, fortunately, an alert nurse intervened and snipped it off close to the gums. Apparently, it was medical grade 'Silastic' used to fill the sinus cavities to keep the cheekbones in place after they had been repositioned. The Red Cross handed out care packages to us patients and I can remember a toothbrush and some toothpaste that remained unused for some time. More so, I remember the efforts that the American Red Cross made to get telegrams to and from my family in Australia. This was especially gratifying for a foreign patient like me in an American hospital in Saigon. The resulting two-way communication was ultra-sweet. Eventually, as the fog cleared, I amended my news to family members from, 'I'll be flying again next week' to 'I'll be coming home for Christmas, just so you won't miss me'. Invaluable reassurance - for correspondents at both ends!

I found out from one of my fellow pilots who managed to visit me in the Saigon hospital that the wreckage of my helicopter was 'wrapped around a steel telegraph pole'. I felt terrible at this news. No pilot wants to think that they have collided with an obstacle or flown into the ground. I told my friend that I understood that all the roadside poles in the crash area were on the western side of Route 15 and, if there had been one or two on the eastern side of the roadway, maybe I had collided with one of them; but I could not imagine colliding with one on the western side. When he confirmed that the pole concerned was on the western side it gave me some small satisfaction, because I was sure that, while I had undoubtedly struck one of them, it was unlikely that the crash was due to 'pilot error'. Nonetheless, I experienced an intense feeling of shame and failure with no way of explaining what else might have contributed to the crash.

Left wondering, and in an information vacuum, I was moved to another US military medical facility at Saigon's Tan Son Nhut airport where patients were tended on camp stretchers while awaiting evacuation from Vietnam. In a journey of many legs, I was flown by RAAF C130 Hercules to an overnight stay in Butterworth in Malaysia, thence to Christmas Island and through the RAAF bases in Western Australia, South Australia 
and Richmond near Sydney. From RAAF Richmond I was transported to the army hospital at Ingleburn. Subsequently I was flown from RAAF Richmond to RAAF Amberly and transported to 1 Military Hospital at Yeronga in Brisbane. I promised myself I would do whatever it took to fly again. This was the beginning of 15 months of anguish and frustration, but I did fly again as an operational pilot. In fact, I flew once again in support of 5 RAR in 1968 as the battalion exercised in preparation for its second tour of duty in Vietnam.

During that exercise, on Holsworthy firing ranges, I was marshalled into an LZ by a 5 RAR soldier who obviously knew what he was doing. After shutting down the Sioux, I chatted to the soldier giving him some well-deserved feedback. At one point he said, 'Yes, I was on the battalion's first tour of Vietnam - I saw a chopper go in [crash].' 'Whereabouts?' I asked, thinking mine might have been the incident he was recalling. 'On Highway 15', he said, confirming that he was speaking of my crash. 'Do you know what happened to the pilot?' I asked. 'Oh, he's a vegetable, I think', he replied. It was a pleasure to introduce myself as a non-vegetative survivor.

Years later, in Perth, I met two former 5 RAR soldiers who also had witnessed to my crash. I was eager to hear anything from eyewitnesses and, although they were cautious with their opinions, they were pretty sure that, for whatever reasons, I had just flown into the steel pylon. I suggested that I knew well the siting of the poles in relation to the road and was careful to keep clear of them. I also told them that when Major Doyle and a fellow Sioux pilot, Second Lieutenant Bob Askew, inspected the wreckage they found Perspex shards with bullet holes in them on the approach to the impact site. Bob Askew had told me this, after I had returned to flying, pointing out that there was also a projectile hole which was in the remains of the rear part of the helicopter's cockpit bubble which would have been right behind where I was sitting.

Further, in January 1967, I received a letter from the commander of 1 ATF, Brigadier David Jackson, telling me the cause of my crash was my having been fired upon. He hoped I wouldn't be too inconvenienced by my injuries and that my Christmas had not been spoiled. While I was very pleased to receive such a letter from our task force commander confirming that I had been brought down by ground fire, my principal concern remained the severe double vision which persisted. Was I ever going to get back to aircrew medical standard? 
My hunger to learn all I could about the crash led me to trawl later through the evidence of the Army Court of Enquiry which began three days after the crash. I was relieved to read in its report that my lingering fears about 'pilot error' were unnecessary. The enquiry found, inter alia, that:

- Small arms automatic fire was heard just prior to the impact and in the direction from which the aircraft was approaching. This was reported by three individuals from C Company, 5 RAR, who were deployed along the road adjacent to the crash site.

- One of my facial injuries was caused by a high-velocity fragment, identity unknown. The attending surgeon from the US 3rd Field Hospital, Saigon, had recorded that my facial injuries appeared to have been caused by a high-velocity fragment which entered on the lower left side of my head and exited on the upper right. The impact would have tended to throw my body to the right and the resulting shock wave would have rendered me unconscious.

- Damage to the Perspex bubble showed possible bullet holes.

Speculation about the cause of my crash has persisted for more than 50 years despite the evidence taken by a Court of Enquiry and its findings. I was glad to learn that my passenger, Staff Sergeant 'Sailor' Mealing, made a full recovery from his injuries and went on to serve another tour of duty in Vietnam. I will always be indebted to those members of 5 RAR who swiftly came to our aid; particularly their medical officer, Captain Tony White, who made an on-the-spot decision that I should be flown directly to a US neurosurgical facility, bypassing the usual casualty evacuation chain. His fortuitous presence nearby and his quick decision probably saved my life.

\section{Editors' conclusion}

Air support played a vital and dynamic part in what 5 RAR achieved during Operations Canberra, Robin and Queanbeyan. The difficulties imposed by the steep jungle terrain of the Nui Thi Vai hills and the constant threat of Viet Cong ground fire were severe tests of the professional skills and courage of the pilots. On completion of operations in the Nui Thi Vai hills our CO, John Warr, conducted a debriefing during which he commended 161 (Indep) Recce Flight on the magnificent job their pilots had done flying in support of the battalion throughout these 
operations. The closeness of their support in the most trying of conditions demonstrated that, being army pilots, they enjoyed a natural affinity for, and a detailed understanding of, an infantry battalion's needs in operations. Their narratives clearly show a magnificent level of devotion to comrades who were locked in ground operations. Understandably, this was an outlook that was inherently more difficult for their RAAF counterparts to acquire. Much more could and should have been done, at all levels in both army and air force hierarchies, to narrow the 'cultural divide' which fuelled the initial and lingering poor understanding of each other's operational imperatives (described in other chapters). 
This text is taken from Vietnam Vanguard: The 5th Battalion's Approach to Counter-Insurgency, 1966, edited by Ron Boxall and Robert O'Neill, published 2020 by ANU Press, The Australian National University, Canberra, Australia.

doi.org/10.22459/VV.2019.14 